\title{
Swot and Pest Analysis of the Volkswagen Group
}

\author{
Marko Šarić ${ }^{*}$, Bojan Rosi ${ }^{2}$
}

${ }^{1} \mathrm{PhD}$ Candidat Faculty of Logistics, University of Maribor, Slovenia, Europa

${ }^{2}$ Professor, Faculty of Logistics, University of Maribor, Slovenia, Europa

\author{
DOI: $10.36347 /$ sjahss.2020.v08i08.003 \\ | Received: 02.07.2020 | Accepted: 15.07.2020 | Published: 16.08.2020 \\ *Corresponding author: Marko Šarić
}

Abstract

Review Article

This paper presents SWOT and PEST analyzes on the Volkswagen Group example. In this paper we present the strengths and opportunities, but also the weaknesses and threats of the mentioned company. The Volkswagen Group demonstrates its strength through the strength of its brands, and the weaknesses are linked to non-competitiveness in the electric motors market. All human resources are well utilized as well as financial flow management. The paper also deals with the political and technological environment in which the company is located and how it is shaped by a new business strategy.

Keywords: Volkswagen group, SWOT, PEST analysis.

Copyright @ 2020: This is an open-access article distributed under the terms of the Creative Commons Attribution license which permits unrestricted use, distribution, and reproduction in any medium for non-commercial use (NonCommercial, or CC-BY-NC) provided the original author and source are credited.

\section{INTRODUCTION}

The aim of this paper is to present a SWOT and PEST analysis of one of the most important automotive groups, the Volkswagen Group. Therefore, the backbone of the seminar is the application of these models to the analysis of Volkswagen. The first part provides a brief overview of the most important information about the Volkswagen Group, such as the number of employees and brands that belong to the group. In the third chapter comes an explanation of the SWOT analysis model, a qualitative analytical method, which shows the current position of the company in the market by analyzing it from four different angles. This section also contains a SWOT analysis of the Volkswagen Group. This provides insight into the state of the group with its positive and negative characteristics. This is followed by an explanation of the PEST analysis model and an example of a PEST analysis on a Volkswagen. Finally, the results of the analyzes are summarized in the conclusion.

\section{Volkswagen Group}

The German automobile industry is considered one of the pillars of the German economy. It was this industry that employed almost 820,000 workers in 2017. About 1.8 million jobs depend directly or indirectly on that automotive industry and bring in a lot of profits, but in the event of a crisis potential market change could lead to problems. In no other country has this industry had such a big impact on generating additional profits as in Germany, and last year every fourth euro was earned in this sector.

The Volkswagen Group (German: Volkswagen Aktiengesellschaft, or Volkswagen AG) was founded in May 1937, and today is one of the largest car manufacturers in the world. The company is headquartered in Wolfsburg, Germany, and has over a hundred manufacturing plants in nearly thirty countries around the world. The largest number of production plants are in Europe, as many as 71, of which 28 are in Germany.

The Volkswagen Group is the largest European car manufacturer, and the original task at the time of its establishment was to produce affordable cars for everyone. During the World War II, production was repurposed for the manufacture of military equipment and vehicles, and in the 1950s there was an expansion of car production for the masses and the export of products. The key to the great success of the Volkswagen Group is the wide range of cars that are attractive to the masses due to their affordable price, but also the offer of more luxurious models, such as Porsche or Lamborghini, for a richer clientele. The Group had almost 643,000 employees worldwide in 2017, of which 44.8 percent were in Germany. With their slogan "Das Auto", they implement the image of their company as the main association with the car. 
Today, the Volkswagen Group owns twelve brands from seven European countries (Volkswagen Passenger Cars, Audi, SEAT, ŠKODA, Bentley, Bugatti, Lamborghini, Porsche, Ducati, Volkswagen Commercial Vehicles, Scania, MAN). According to the results from the first quarter of 2018, Volkswagen is in second place in terms of the number of cars sold with 2.3 million sales. Toyota is still in first place with 2.81 million vehicles sold.
In April 2018, the chairman of the company is Herbert Diess, who announces changes in the business approach and presentation. Volkswagen is still recovering from the 2015 crisis caused by the scandal in which diesel cars gave false results on the eco-test. The group suffered material damage of several billion euros, but also called into question its reputation as one of the leading car manufacturers. Therefore, the question arises as to what the current position of the Volkswagen Group is in the market and what are the opportunities and threats facing it.

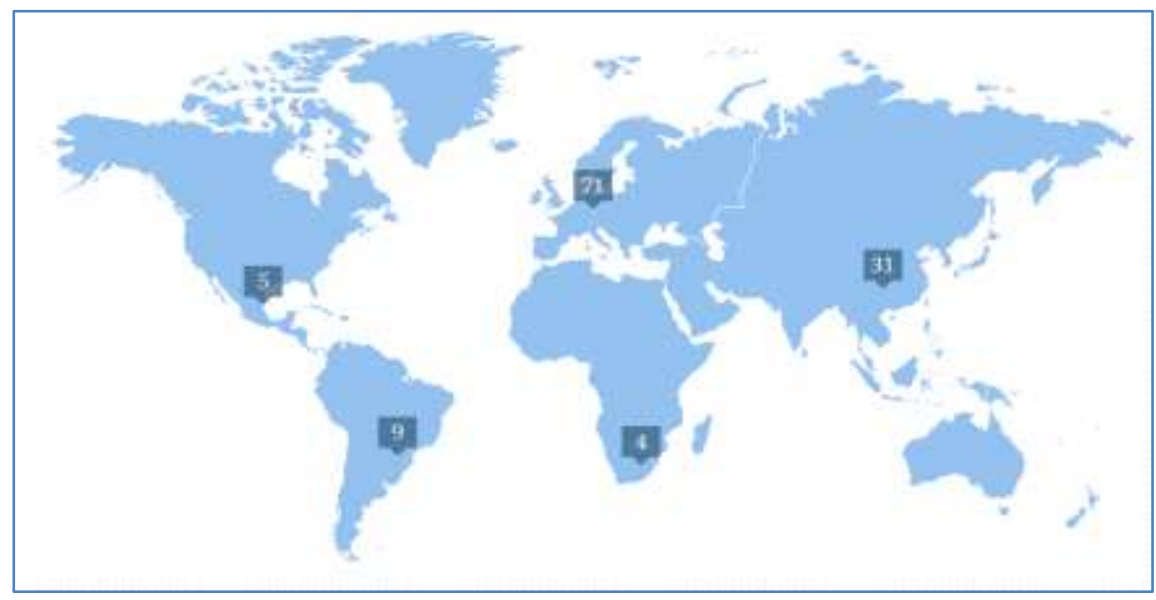

View-1: Volkswagen production plants by continent

\section{SWOT analysis}

SWOT Analysis is a qualitative method of reviewing four groups of characteristics of a company or organization. The name comes from the English abbreviation for Strengths, Weaknesses, Opportunities and Threats. SWOT analysis can be defined as a dynamic and multidimensional tool that enables the diagnosis of strengths and weaknesses and the visualization of opportunities and dangers within a matrix of four defined fields. The focus is on both the internal and external environment of the organization. The internal environment includes the strengths and weaknesses of a company, such as company resources, and the external environment consists of opportunities and threats, or (un) favorable factors for the growth and development of the company. SWOT analysis is a situational analysis because it shows the position of the company at a time in the market.

Strengths are the positive characteristics of a company that are within its control. These characteristics should be maintained and used as advantages over others. Weaknesses are factors that are also within the control of the company, but they place the company at a disadvantage (weaker position) compared to the competition. Weaknesses need to be removed and stopped. As opportunities we define the elements in the environment that represent the reasons for the progress and survival of the company in the market. The company should use these opportunities to its advantage to empower in the future. Threats also belong to the elements of the external environment, are not within the control of the company and pose a risk to it.

The concept of SWOT analysis is attributed to Albert Humphrey, who conducted research on many leading companies at Stanford in the 1960s and 1970s. The use of SWOT analysis is widely used and is not limited to analyzing companies but is also used in analyzing cultural projects in NGOs. organizations, etc. This tool helps to explore new solutions to problems due to its intention to consider the internal and external factors that affect the positioning in the wider plan.

Through SWOT analysis, we can reduce their impact by detecting weaknesses and threats by taking advantage of the opportunities that open with further analysis. 
Marko Šarić \& Bojan Rosi., Sch J Arts Humanit Soc Sci, August, 2020; 8(8): 414-419

\begin{tabular}{|c|c|}
\hline \multicolumn{2}{|l|}{ VOLKSWAGEN SWOT ANALYSIS } \\
\hline STRENGTHS & WEAKNESSES \\
\hline$\checkmark \quad$ Includes many brands & $\checkmark \quad$ the impact of the 2015 diesel scandal on \\
\hline$\checkmark \quad$ Synergy between brands & sales and reputation \\
\hline$\checkmark \quad$ Diverse offer: cars, motors and bus production & $\checkmark \quad$ most cars are not environmentally friendly \\
\hline$\checkmark \quad$ Production in 120 countries & $\checkmark \quad$ poor market position in the US \\
\hline$\checkmark \quad$ High brand recognition & $\checkmark$ poor market position in India \\
\hline$\checkmark \quad$ Named the world's most creative advertiser in 2017 & $\checkmark \quad$ lowness in the electric car market \\
\hline$\checkmark \quad$ Large number of employees & $\checkmark \quad$ strong competition: Toyota as the best- \\
\hline$\checkmark \quad$ Increase in profit - recovery & selling brand in the last quarter \\
\hline$\checkmark \quad$ Desirable employer & \\
\hline$\checkmark \quad$ Strong German car industry & \\
\hline \multicolumn{2}{|l|}{ Favorable position in the Chinese market } \\
\hline OPPORTUNITIES & THREATS \\
\hline$\checkmark \quad$ new strategy "TOGETHER - 2025" & $\checkmark \quad$ worse reputation after the diesel scandal and \\
\hline$\checkmark$ implementation of innovations - cars with & the withdrawal of many cars \\
\hline renewable energy, autonomous vehicles & $\checkmark \quad$ declining consumer confidence \\
\hline$\checkmark \quad$ new models with fuel efficiency & $\checkmark \quad$ rising and strengthening competition \\
\hline$\checkmark \quad$ announced change of VW logo for year 2019 & $\checkmark \quad$ rising fuel prices \\
\hline$\checkmark \quad$ expansion in the Asian market & $\checkmark \quad$ falling of the euro \\
\hline$\checkmark \quad$ reduction of fuel prices & \\
\hline$\checkmark \quad$ strengthening of the euro & \\
\hline
\end{tabular}

The strength of the Volkswagen Group is the ownership of number of brands, specifically twelve of them. Thus, they have a wide range of offers for their clients, which offers them room for maneuver for earnings by clients of different economic views. Volkswagen produces good and sustainable vehicles among all its brands and types of vehicles, such as Ducati engines, MAN buses or Bugatti luxury sports cars.

Apart from the fact that the offer is very diverse, synergy has been maintained among all brands and there is no lack of recognition in the market. This is confirmed by the fact that in 2017 Volkswagen was named the most creative advertiser in the world in 2017.
In 2017 the group had almost 643,000 employees worldwide and research in Germany suggests that VW's Audi is one of the most desirable places to work in the automotive industry, which in a country with so many employees in the automotive industry can only point the strength of this brand and the power of this industry on the German economic level. Another strength in the series is the visible financial recovery after the 2015 crisis. Sales revenues and gross profit in 2017 are higher than in the years before the crisis.

View 2: VW financial data from 2013 to 2017.

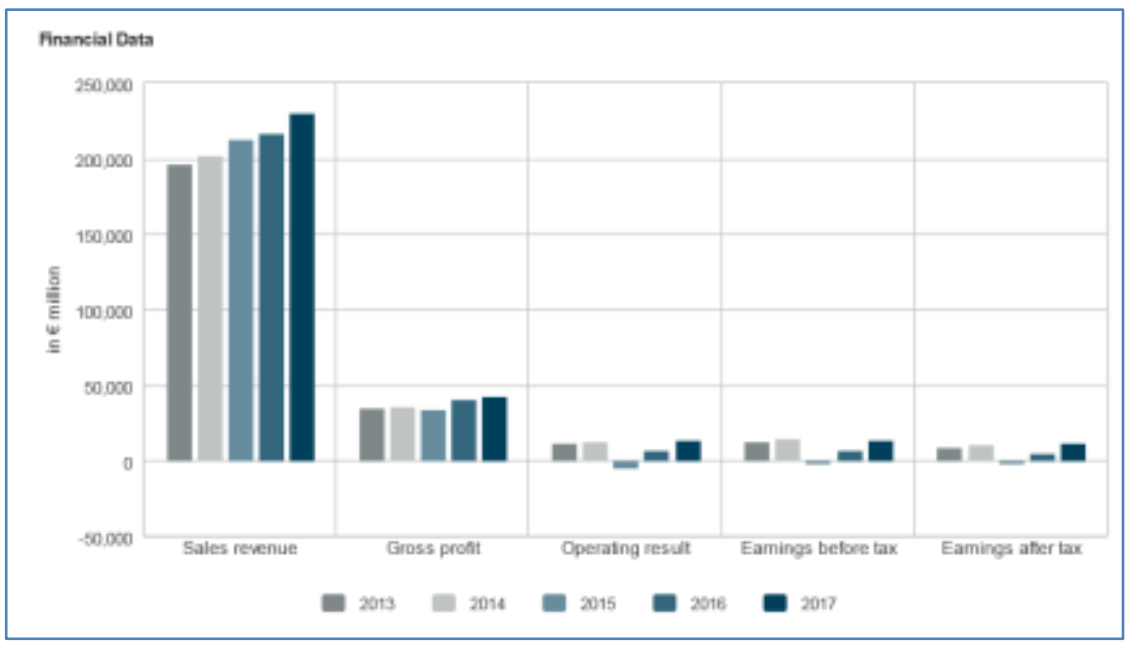

A presence in markets around the world completes the image of Volkswagen as a strong company. It has its base and the biggest influence on the German market, but it is breaking into the Chinese and Brazilian markets. China, as a growing economic power, recorded a four percent increase in VW model sales in 2017, and predictions for this year are also good and at least equal or slightly greater success is expected. 
Volkswagen plans to export vehicles manufactured in the Chinese market to Southeast Asia and thus become a growing player in the fast-growing automotive market in the area.

The obvious weakness of Volkswagen is the diesel scandal in 2015, which caused large economic losses in the billions. In addition to the fact that many were withdrawn, there was a drop in trust in the company among customers. The scandal has damaged the company's reputation in the United States, but also around the world. In a 2016 survey, 42 percent of respondents confirmed that their opinion of Volkswagen had deteriorated due to the diesel affair, and only 7 percent said Volkswagen was completely credible.

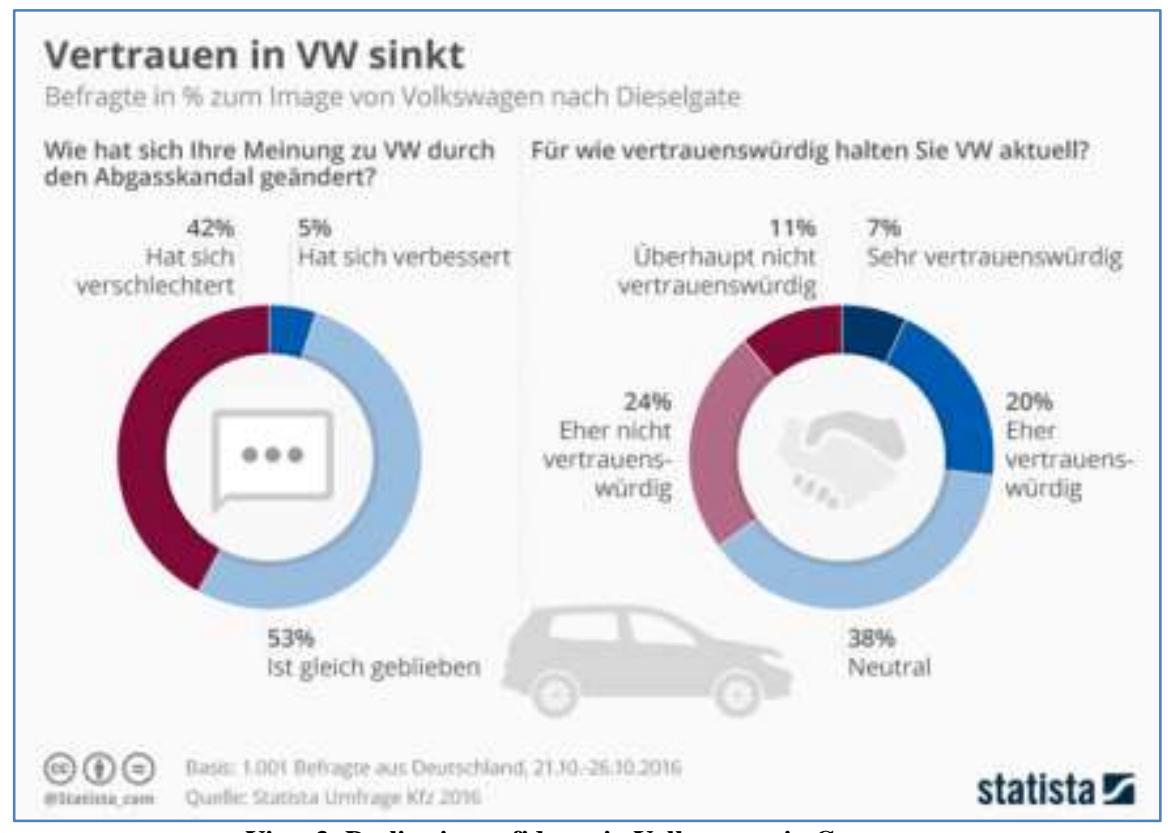

View-3: Decline in confidence in Volkswagen in Germany

One of the disadvantages they must face is the lack of environmentally friendly vehicles on offer. Their three most attractive brands, Bugatti, Lamborghini, and Porsche emit an excessive amount of carbon dioxide, which can harm the company if changing of regulations happen. This leads to the next weakness which is the non-existence of Volkswagen's electric car model that would be competitive in the market and show their new path and commitment to environmental protection after the scandal.

Volkswagen currently has six production facilities in India, a large emerging market, and the biggest competitors there are Hyundai and Maruti. As a result, his position is weak, and he is not able to compete with them at a higher level. On the world stage, Volkswagen is in second place among the bestselling vehicles in the last quarter, while the first place is held by another Asian brand - Toyota. Volkswagen produces luxury cars, not just middle-class vehicles.

Opportunities for the Volkswagen Group are the announced changes and the strategy "TOGETHER 2025" in which numerous changes have been announced. Among other things, the installation of particulate filters on engines, autonomous vehicles and over thirty new electric cars are expected, by which they want to make electric mobility their trademark. Such vehicles are the future of the automotive industry.

After almost seven years, the Volkswagen logo is also changing, which is an opportunity for a new introduction to the market. As part of the new plan and new leadership, Volkswagen strives to become a modern, more successful, and transparent company.

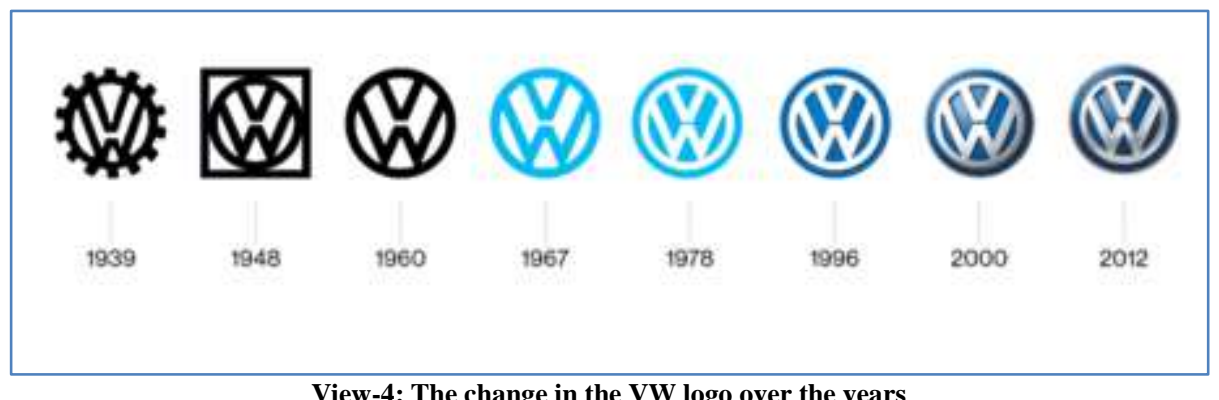

View-4: The change in the VW logo over the years 
Expanding its impact on the Asian market would open a new opportunity for the company to succeed and thrive as Asia has some of the fastest growing economies in the world.

Since many Volkswagen vehicles are still not electric vehicles, reducing fuel prices could increase their sales.

In the area of threats to Volkswagen, it is worth noting that the bad reputation can still follow the brand and call into question all products and statements. Although the company is recovering from the scandal, the decline in customer confidence is still a current and serious matter for one of the best car manufacturers. Their decline could be exploited by competition and thus create dominance in markets around the world, a discount for Toyota and Ford in Bangladesh and India, where Volkswagen had a small market share.

\section{PEST ANALYSIS}

Very often, as a supplement to the SWOT analysis, the PEST analysis model appears, which is based on the study of the political and legal economic, socio-cultural, and technological environment of a certain company. The task of such an elaboration is to notice and indicate the factors that affect the current and future situation of the company.

The political and legal environment dictate the development of the market through the regulation of the law of market availability for domestic and foreign investors. The stability of the market also depends on the stability of the political situation in the country and therefore determines the economic picture of the country, whether it leads to a positive or negative economic situation. The sociocultural environment includes existing social attitudes, the level of education of the population, religious affiliation, and trends. The technological environment is defined by infrastructure and innovation and the improvement of production processes.

\section{Volkswagen group - pest analysis}

\begin{tabular}{|c|c|}
\hline \multicolumn{2}{|l|}{ VOLKSWAGEN PEST ANALYSIS } \\
\hline POLITICAL AND LEGAL ENVIRONMENT & ECONOMIC ENVIRONMENT \\
\hline $\begin{array}{l}\checkmark \quad \begin{array}{l}\text { constantly facing numerous political and legal } \\
\text { regulations due to presence in the markets of }\end{array} \\
\text { over } 150 \text { countries (trade policy) } \\
\checkmark \quad \text { financial sector is dependent on the state and its } \\
\text { investment in the automotive industry } \\
\checkmark \quad \text { adaptation challenge (example China) }\end{array}$ & 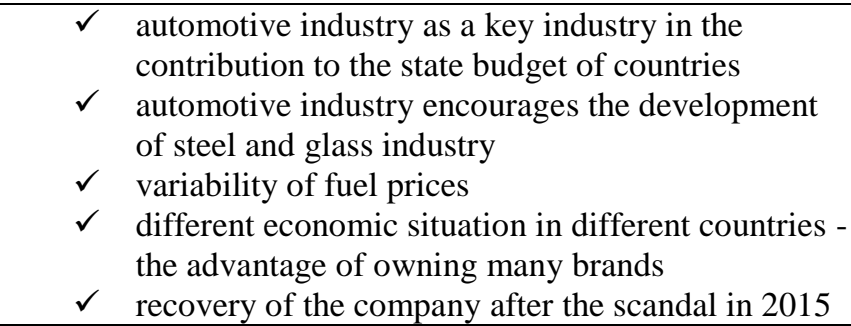 \\
\hline SOCIOCULTURAL ENVIRONMENT & TECHNOLOGICAL ENVIRONMENT \\
\hline $\begin{array}{ll}\checkmark & \text { lost trust and worse reputation among } \\
\text { customers after the diesel scandal } \\
\checkmark & \text { global increase in sense of social } \\
\text { responsibilities for climate change and } \\
\text { environmental protection } \\
\checkmark \quad \text { large number of employees around the world } \\
\checkmark \quad \text { growing interest in electric cars }\end{array}$ & $\begin{array}{ll}\checkmark & \text { investment in research and development } \\
\checkmark & \text { development of technology with increasing } \\
\text { production of hybrid and electric vehicles and } \\
\text { autonomous vehicles }\end{array}$ \\
\hline
\end{tabular}

The political factors of the environment are numerous and vary from state to state. The Volkswagen Group, as an international company, must be ready to adapt to diverse markets and become familiar with all laws and trade policies. The automotive industry is also one of the keys to achieving a higher GDP of a country. This industry, along with its development, encourages the development of many other industries, such as the glass and steel industry. The uncertainty of economic conditions is also reflected in the company's profit. A bad economic situation in a certain country will hinder sales because the crisis weakens purchasing power and often makes it impossible to buy new vehicles. The advantage of the Volkswagen Group is that it can adapt to the market and offer both cheaper and more expensive vehicle models from its wide range.
With Volkswagen employing almost 643,000 employees, the group is directly dependent on the manufacturer, and in its new strategy, the group states that its goal is to be an excellent employer that offers many opportunities and a motivating environment for its employees.

Although trust in the company has been shaken, with their new strategy they want to offer their customers a tailor-made product. They want to delight old and attract new customers with the best service, impeccable quality, and outstanding reputation. What enables them to do so is a shift in focus to the production of electric, hybrid and autonomous vehicles and a commitment to preserving the environment. This leads to the 
development of new infrastructures and the use of new technologies and greater competitiveness in the market.

\section{CONCLUSION}

Despite the diesel affair in 2015, the Volkswagen Group managed to be the best-selling car brand next year. In fiscal year 2017, the group delivered 10.7 million vehicles to customers worldwide, setting a record. Volkswagen is one of the largest employers in the private sector. In fiscal year 2017, Volkswagen Group sales revenue increased by $6.2 \%$ year on year to EUR 230.7 billion

All these data clearly show the strength and influence of this company in the global market and open the possibility for its even greater success. The "TOGETHER - 2025" strategy emphasizes the implementation of innovations in the work on branding Volkswagen as a "green" company that cares about preserving the environment. It seems that in doing so, they decided to use their greatest weakness from a few years ago as an opportunity for progress.

Opportunities to improve the market position lie in expanding to the Asian market and introducing new models of electric and autonomous vehicles, which is stated in their new plan.

Strong competition can be a threat to business, but also an incentive to improve services, products, and technological advances. This German manufacturer can restore the trust of its customers and set new trends in the automotive industry.

\section{LITERATURE}

1. Gamble JE, Strickland AJ, Thompson AA. Strateški menadžment, 14. izdanje Zagreb, Mate d.o.o. 2008.

2. Šarić M, Šprem B. SWOT i PEST analiza Savezne Države Bavarske. Zbornik radova Međimurskog veleučilišta u Čakovcu. 2017; 8(1): 89-99.
3. Volkswagen Annual Report 2017: http://annualreport2017.volkswagenag.com/ (7.6.2018.).

https://www.volkswagenag.com/en/group.html

4. http://annualreport2017.volkswagenag.com/service pages/keyfigurescomparison.html\#/datasheetvw_ar/vertbar/3,4,5,6,7/0,1,2,3,4/figures/0 https://www.britannica.com/topic/VolkswagenGroup https://focus2move.com/world-cars-brandranking/ https://www.bloomberg.com/news/articles/201804-16/vw-to-tweak-logo-in-marketing-reset-forelectric-car-era

5. https://www.marketing91.com/swot-analysis-ofvolkswagen/

6. https://www.strategicmanagementinsight.com/tools /pest-pestel-analysis.html

7. https://www.volkswagen.hr/novosti/novosti/5715volkswagen-je-najkreativniji-oglasivac-na-svijetu

8. https://karrierebibel.de/beste-arbeitgeber-2018/

9. https://de.statista.com/infografik/6868/vertrauenin-vw-nach-dieselgate/

10. https://de.statista.com/statistik/daten/studie/468682 /umfrage/abgas-skandal-von-vw-schaden-fuerdeutsche-wirtschaft/

11. https://de.statista.com/statistik/daten/studie/30743/ umfrage/umsatz-der-volkswagen-ag/

12. https://de.statista.com/statistik/daten/studie/468413 /umfrage/vom-abgas-skandal-betroffene-fahrzeugevom-volkwagen-konzern/

13. https://www.bloomberg.com/quote/VOW:GR

14. https://rapidbi.com/swotanalysis/

15. http://www.poslovni.hr/leksikon/swot-analiza-1528

16. https://www.focus.de/finanzen/news/sokommentiert-deutschland-winterkorn-skandal-vwkann-sich-in-deutschland-alles-erlauben-waspolitisch-und-moralisch-unakzeptabelist_id_8886687.html

17. http://europe.autonews.com/article/20180209/BLO G15/180209760/vw-has-fixed-its-china-operationsand-is-now-set-to-keep-its-lead. 